\title{
CARACTERIZAÇÃO GEOMORFOMÉTRICA APLICADOS AOS ESTUDOS SOBRE A MORFODINÂMICA DA BACIA HIDROGRÁFICA DO CÓRREGO SÃO JOSÉ - MUNICÍPIO DE ITUIUTABA/MG
}

\author{
Leda Correia Pedro Miyazaki \\ Universidade Federal de Uberlândia, Instituto de Ciências Humanas do Pontal \\ Programa de Pós-graduação em Geografia do Pontal, Ituiutaba, MG, Brasil \\ lecpgeo@ufu.br \\ Fabio Reis Venceslau \\ Universidade Federal de Uberlândia, Instituto de Ciências Humanas do Pontal \\ Programa de Pós-graduação em Geografia do Pontal, Ituiutaba, MG, Brasil \\ vennceslau@gmail.com
}

\begin{abstract}
RESUMO
Estudar uma bacia hidrográfica é de grande importância para o manejo do solo, o planejamento urbano-ambiental ou ordenamento territorial, pois ao se conseguir informações e dados sobre as características físicas, modelos de parcelamento do uso e ocupação, aspectos socioeconômicos, a gestão e o gerenciamento tornam-se mais efetivos. São nas bacias urbanas que os impactos são mais expressivos, pois o equilíbrio dinâmico dos processos naturais é rompido e, os efeitos assim como as respostas desse rompimento são manifestados por meio dos problemas ambientais urbanos que atingem parte da sociedade. Pensando-se nessa problemática, o objetivo desse estudo foi realizar a caracterização geomorfométrica da bacia hidrográfica do Córrego São José, que atualmente encontra-se bastante urbanizada, para subsidiar os estudos sobre a morfodinâmica. Entendida aqui como o estudo quantitativo de uma bacia, que resulta na medida de aspectos do relevo e dos canais fluviais. Para tanto, foram adotados como procedimentos metodológicos a revisão bibliográfica sobre a temática, os trabalhos de campo e um banco de dados elaborado em ambiente SIG. Assim, os resultados obtidos a partir da análise dos parâmetros geomorfométricos demostraram que a bacia está susceptível a sofrer enchentes medianas; evento observado nas áreas de fundo de vale, nos períodos de ocorrência de alto volume de precipitação, que é agravado pela ação antrópica, que impermeabiliza o solo na vertente e fundos de vale na área urbana, além das erosões lineares e assoreamento na área rural.
\end{abstract}

Palavras-chave: Geomorfometria. Bacia Hidrográfica. Córrego São José. Morfodinâmica.

\section{GEOMORPHOMETRIC CHARACTERIZATION APPLIED TO STUDIES ON THE MORPHODYNAMICS OF THE SÃO JOSÉ WATERSHED - ITUIUTABA / MG}

\begin{abstract}
Studying a hydrographic basin is of great importance for soil management, urbanenvironmental planning or territorial ordering, because when obtaining information and data on its physical characteristics, its models for the division of use and occupation, socioeconomic aspects, management and administration become more effective, especially in urbanized watersheds. It is in urban basins that the impacts are most significant, since the dynamic balance of natural processes is disrupted and the effects as well as the responses to this disruption are manifested through urban environmental problems that affect part of society. With this problem in mind, the objective of this study was to carry out the geomorphometric characterization of the São José Watrshed, which is currently quite urbanized, to support studies on morphodynamics. Morphometry is understood here as the quantitative study of a watershed, which results in the measurement of aspects from the relief and from the river channels. To this end, the bibliographic review on the subject, fieldwork and a database prepared in a GIS environment were adopted as methodological procedures. Thus, the results obtained from the analysis of the geomorphometric parameters show that the watershed is susceptible to median flooding; event observed in the valley bottom areas, in periods of high rainfall volume, highlighting the anthropic action in the waterproofing of the soil in the slope.
\end{abstract}

Keyword: Geomorphometry. Watershed. São José Stream. Morphodynamics. 


\section{INTRODUÇÃO}

Estudar uma bacia hidrográfica é de grande importância para o manejo do solo, o planejamento urbanoambiental ou ordenamento territorial dos municípios, pois ao se conseguir informações e dados sobre suas características físicas, aspectos socioeconômicos, modelos de parcelamento dos usos e ocupação, a gestão e o gerenciamento tornam-se mais eficazes, sobretudo, em bacias hidrográficas urbanizadas. São nessas bacias que os impactos se tornam mais expressivos, pois o equilíbrio dinâmico dos processos naturais é rompido, e os efeitos e as respostas para isso são manifestados por meio dos problemas ambientais urbanos que comprometem, tanto a qualidade de vida da sociedade, quanto do ambiente em que vivem.

Quando a expansão territorial urbana ocupa grande parte de uma bacia hidrográfica, os processos naturais, tais como o escoamento superficial, infiltração e percolação das águas pluviais, evapotranspiração, transporte e deposição de sedimentos, entre outros, são alterados. Isso gera uma série de impactos na bacia, somente a título de exemplo pode-se citar as bacias que são ocupadas por loteamentos ou bairros para fins de moradia. A primeira intervenção realizada pela ação do homem é a retirada da cobertura vegetal, seguida pela retificação do relevo (cortes de talude nas vertentes e construção de aterros), pelo processo de terraplanagem e a edificação dos lotes delimitados, que em seguida são impermeabilizados podendo possuir terrenos totalmente impenetráveis pelas águas pluviais. Essas intervenções associadas ao período de chuva, são capazes de gerar em algumas bacias hidrográficas urbanizadas fortes enxurradas (oriundas das precipitações e escoamento superficial) que podem atingem determinados locais dos bairros, com tamanha velocidade e concentração de águas pluviais que geram alagamentos nos fundos de vale, derrubam muros das residências, ou até mesmo causam incisões lineares no solo dando origem as erosões urbanas.

Nesse sentido, conhecer a dinâmica dos processos naturais, ou melhor a morfodinâmica de uma bacia hidrográfica, destacando as características naturais do ambiente e os aspectos socioeconômicos são importantíssimos para se evitar e minimizar impactos socioambientais.

Os estudos sobre a morfometria de uma bacia hidrográfica podem fornecer dados e modelos que são capazes de expressar as principais características e os processos mais atuantes no local, contribuindo para o planejamento, ordenamento e a gestão. Pensando-se nisso, utilizou-se nessa pesquisa o conceito de geomorfometria, entendido aqui como o estudo da geometria da bacia a partir de uma concepção geográfica e geomorfológica, que considere a relação sociedade e natureza, os efeitos e as respostas do ambiente diante a intervenção humana e o rompimento do equilíbrio dinâmico dos processos naturais. $\mathrm{O}$ estudo quantitativo de uma bacia, resulta na medida de aspectos do relevo evidenciando medidas de altura, comprimento, largura, superfície, volume, altura absoluta e relativa, inclinação, curvatura, orientação, densidade e frequência de suas formas, ou seja, aspectos hipsométricos e declividades. Tudo isso, para serem aplicados aos estudos com ênfase na ocupação do relevo, se materializando por meio das rugosidades identificadas na paisagem e que constitui o espaço geográfico.

Os estudos geográficos com ênfase na morfodinâmica das bacias hidrográficas urbanas exigem investigações que trabalhem de forma integrada, considerando tanto a dinâmica da natureza, quanto a dinâmica da sociedade. Assim, será possível compreender como o ser humano é capaz de esculturar o relevo, por meio da ocupação e acelerar processos naturais tais como os erosivos, o de escoamento, assoreamento etc., uma vez que, o ser humano é considerado por muitos pesquisadores como um agente acelerador dos processos geomorfológicos.

É nesse sentido que a presente pesquisa selecionou a bacia hidrográfica do córrego São José como recorte espacial, por se tratar de uma área que está sendo cada vez mais urbanizada e onde inúmeros impactos socioambientais são identificados. Assim, a investigação procurou demonstrar como a caracterização geomorfométrica contribuiu efetivamente para os estudos sobre a morfodinâmica de uma bacia hidrográfica, pois forneceu uma série de dados e modelos que permitem gerar cenários futuros para subsidiar a tomada de decisão de um grupo gestor.

O município de Ituiutaba está situado na porção Oeste do Estado de Minas Gerais, na região do Triângulo Mineiro, cujas coordenadas geográficas $49^{\circ} 52^{\prime} \mathrm{W} / 49^{\circ} 10^{\prime} \mathrm{W}$ e $18^{\circ} 36^{\prime} \mathrm{S} / 19^{\circ}, 21^{\prime} \mathrm{S}$. A bacia pesquisada (Figura 1), possui um perímetro de aproximadamente $38,958 \mathrm{~km}$ e uma área de $73,628 \mathrm{~km}^{2}$, que equivale a $7.362,80$ hectares. Analisando a área da bacia e comparando com a área urbana do município é importante ressaltar que aproximadamente $87 \%$ de toda a área urbana localiza-se dentro da bacia hidrográfica do córrego São José, que possui uma importante função, sendo responsável por drenar maior parte das águas pluviais da área de estudo. 
A bacia é composta por três canais fluviais, sendo o córrego São José, córrego Pirapitinga e o córrego do Carmo, todos possuem suas nascentes nas áreas mais elevadas onde se encontram os relevos do tipo tabuliforme (concentrados na área rural) e percorrem a área urbana, onde estão os relevos de colinas, até desaguar no Rio Tijuco, que é o nível de base.

Figura 1 - Localização da Bacia Hidrográfica do Córrego São José - Ituiutaba/MG

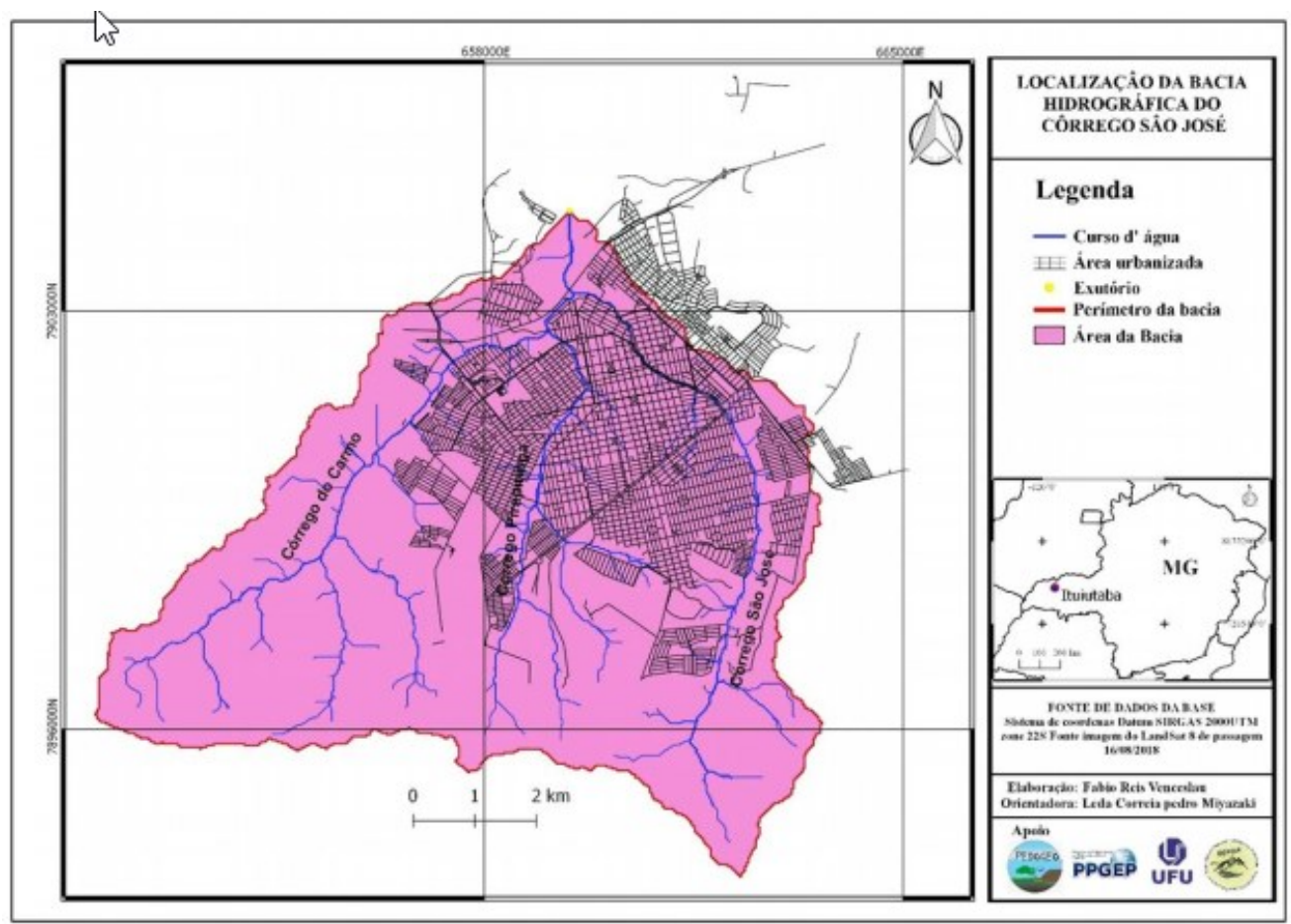

Elaboração: Autores (2020)

Pensando-se nessa problemática, o objetivo desse estudo foi realizar a caracterização geomorfométrica da bacia hidrográfica do córrego São José, que atualmente se encontra bastante urbanizada, para subsidiar os estudos sobre a morfodinâmica. Considera-se a pesquisa relevante, pois a bibliografia científica sobre a temática abordada no município de Ituiutaba- MG ainda é escassa, principalmente aquelas trabalhadas na escala de análise do local. Esse estudo, contribuirá de forma significativa para o ordenamento territorial na Microrregião Geográfica de Ituiutaba-MG.

\section{Discussão teórica}

Estudar uma bacia hidrográfica é de grande importância, pois ao se conseguir informações e dados sobre as características físicas, modelos de parcelamento, usos e ocupação do solo ou aspectos socioeconômicos, a gestão e o gerenciamento tornam-se mais eficazes (TORRES, MACHADO, 2012).

A fim de entender a bacia hidrográfica e a interconexão entre os elementos que a constitui é importante compreender primeiro a definição. Essa pode ser compreendida como uma área drenada por um determinado rio, funcionando de forma aberta, em que cada um dos elementos, matérias e energias presentes, possuem uma função própria e estão estruturados e intrinsecamente relacionados entre si (CHRISTOFOLETTI, 1980).

A bacia hidrográfica pode ser analisada geomorfológicamente a partir da concepção dos compartimentos geomorfológicos. Nos estudos realizados por Pedro Miyazaki (2014), é possível identificar e delimitar três compartimentos sendo esses os topos, as vertentes e os fundos de vale. A compartimentação do relevo de uma área pode auxiliar na compreensão dos processos que deram origem as formas de uma determinada área, além de contribuir para o entendimento da fisiografia da paisagem e também a morfodinâmica da bacia. 
Assim, para compreender a morfodinâmica que ocorre em uma bacia hidrográfica, com ênfase nos processos exógenos é importante entender e identificar como a circulação da água acontece, além da esculturação do relevo e das características geomorfométricas.

A dinâmica que envolve os processos naturais ocorre principalmente devido ação das águas pluviais, que são consideradas como um agente modelador e modificador da paisagem. A água assume diferentes estados e trajetórias ao longo de sua circulação, por meio da precipitação desencadeia uma série de processos e possíveis trajetórias, que dependem não só das características da água, mas, sobretudo, dos atributos e condições das diferentes componentes por onde irá circular (BOTELHO, 2011).

A água é uma substância que pode ser encontrada de três formas no planeta terra, líquida, sólida e gasosa. Está presente em diversos ambientes como atmosfera, oceanos, mares, lagos e subsolo, permanecendo em constante movimento pelo planeta. A circulação é conhecida como ciclo hidrológico mudando de estado na medida que percorre as etapas do ciclo conhecidas como precipitação, evaporação, condensação, intercepção, infiltração e escoamentos superficial ou subsuperficial (TORRES E MACHADO, 2012). Pensando-se no ciclo hidrológico, a água ao atingir a superfície terrestre revestida por uma cobertura vegetal, do tipo floresta tropical, assume diversos caminhos. Pode ser interceptada pela copa das árvores e evaporar para a atmosfera, ou ser armazenada na copa e ocorrer a evaporação, seguida de precipitação. É possível também escoar pelos troncos e atingir com menor velocidade a superfície, podendo fluir superficialmente ou infiltrar no solo. Isso dependerá das características intrínsecas dos tipos de solos, das condições do relevo, entre outros componentes (TRICART, 1977). Isso representa um equilíbrio dinâmico dos processos naturais. No momento que a água infiltra no solo poderá percolar e abastecer as nascentes dos cursos d'água, ou atingir profundidades, aprovisionando os lençóis ou aquíferos freáticos. Caso ocorra o escoamento superficial, processo responsável pelo transporte e deposição dos sedimentos, pode ocasionar eventos como enchentes ou cheias (GUERRA e CUNHA, 2008), assorear canais fluviais e contribuir direta e indiretamente com os episódios de enchentes, inundações e alagamentos na bacia.

Nessa mesma perspectiva Coelho Netto, (2008, p.93) apresenta, dentre "as múltiplas funções da água destacamos seu papel como agente modelador do relevo da superfície terrestre, controlando tanto a formação como comportamento mecânico dos mantos de solos e rochas". O transporte destes materiais depende dos agentes envolvidos, no caso de uma bacia hidrográfica os elementos podem ser águas pluviais, fluviais, movimentos de massas, ação eólica e gravitacional, este transporte pode ser por atividades mecânicas e hidráulicas (SUGUIO, 2003).

De posse destas premissas é notório que a força motriz de uma bacia hidrográfica são os fluxos que ocorrem tanto nos topos, vertentes e nos fundos de vale, sendo os cursos d'água, responsáveis pelos processos de transporte e deposição de matérias oriundos das vertentes e do próprio canal fluvial. Os canais podem apresentar aspectos diferentes, que variam de acordo com as rochas, os solos e o clima de uma determinada localidade. Neste sentido, compreender a morfodinâmica que envolve a interferência do ser humano no momento que acontece a apropriação e ocupação do relevo é fundamental para os estudos da bacia hidrográfica, sobretudo, nas áreas urbanas.

Segundo Ross (2005) o homem é um ser pensante, capaz de gerar riquezas, cujas suas ações interfere no meio natural, provocando alterações no local, retirando a cobertura vegetal parcialmente ou por completo. Isto é evidenciado nas áreas urbanas, nas atividades de produção do meio rural, nos locais onde são instalados hidrelétricas, em rodovias, etc. É passível sob a ótica dos processos morfodinâmicos (tempo atual), que a dinâmica de escoamento dos canais fluviais em uma bacia hidrográfica urbana, apresentam áreas consideradas como instáveis. Isso ocorre segundo Casseti, (1991) quando as vertentes da bacia hidrográfica começam a ser ocupadas, com a retirada da cobertura vegetal, as relações processuais morfodinâmicas se alteram, ou seja, rompesse o equilíbrio dinâmico dos processos naturais, onde "os solos são castigados diretamente pela incidência dos raios solares e efeitos pluvioerosivos, além de permitir aumento da velocidade dos ventos, o que favorece a dessolagem" (CASSETI, 1991, p. 47)

A impermeabilização do solo nas áreas urbanas dificulta o abastecimento do lençol/aquífero freático e, em contra partida, o volume de d'água proporcionado pelo escoamento superficial, chega com maior velocidade aos canais fluviais. Nesse sentido, Casseti (1991, p. 72) diz que essa intervenção rebate a "redução substancial da infiltração, com consequente acréscimo do escoamento superficial. Diante disso, tem-se a redução do abastecimento do lençol freático, o que implica despe-renização dos cursos d 'água, ao mesmo tempo em que responde por suas descargas excepcionais" mudando o fluxo das chuvas torrenciais. 
Nas áreas rurais a instabilidade é evidenciada pelas grandes áreas que sofrem com a retirada da vegetação, com a desagregação do solo para o cultivo e a remoção das matas ciliares. Estes fatores incidem diretamente na dinâmica fluvial dos canais. Diante deste cenário, o emprego das técnicas atrelado à ciência contribui, tanto para acelerar a degradação, devido ao modo como às práticas são empregadas na apropriação das vertentes de uma bacia, quanto para a aplicação de medidas mitigação, que buscam entender os processos da evolução do relevo para minimizar o desequilíbrio gerado pela sociedade na sua relação 'sociedade-natureza'.

Atualmente, o conhecimento aplicado nos estudos das bacias hidrográficas, vem contribuindo para as análises ambientais, sendo utilizada nos monitoramentos da taxa de erosão de bacias e assoreamentos de canais fluviais, lagos e reservatórios de usinas hidrelétricas, também para se compreender a dinâmica das enchentes, inundações e alagamentos e nos movimentos de massa. Tais estudos se baseiam na morfodinâmica (tempo atual) com foco nos eventos atuais, fato que coloca o ser humano como um dos agentes que mais contribui para a modelagem do relevo (VENCESLAU; PEDRO MIYAZAKI, 2019).

O estudo das bacias hidrográficas com áreas urbanas e rurais, tanto no âmbito de caráter físico (com destaque para as análises geomorfométricas), quanto os econômicos, sociais e de uso e ocupação, são fundamentais para que se pratique o ordenamento, o manejo e a gestão adequada, sendo capaz de minimizar os possíveis desequilíbrios na bacia, principalmente em relação a questão hídrica.

A análise geomorfométrica é importante no contexto das bacias hidrográficas, pois através dos parâmetros obtidos é possível identificar sua predisposição em relação a ocorrência de acontecimentos e sua resposta à ação antropogênica no uso e ocupação da terra.

\section{METODOLOGIA}

A revisão bibliográfica foi o ponto de partida da pesquisa, pois ao se revisar conceitos básicos sobre a temática, pode-se elaborar uma contextualização teórico-metodológica que a balizou, onde os conceitos de bacia hidrográfica, rede de drenagem, morfometria, ocupação, relevo e a morfodinâmica foram fundamentais para se entender as principais características.

Os trabalhos de campo foram basilares para o desenvolvimento do estudo, pois envolveram etapas de reconhecimento da área, identificação de impactos socioambientais e validação dos mapeamentos temáticos gerados em ambiente SIG (Sistemas de Informação Geográfica).

Para se estudar a morfodinâmica de uma bacia hidrográfica foi necessário caracterizá-la e para isso a geomorfologia, por meio do estudo do relevo e a análise geomorfométrica foram fundamentais. A elaboração do banco de dados foi outra etapa importante da pesquisa, pois através do programa QGIs foi possível gerar e obter os dados morfométricos e posteriormente realizar uma análise geomorfométrica da bacia. Os principais parâmetros morfométricos utilizados para analisar a dinâmica, ou seja, a morfodinâmica da bacia hidrográfica foram: Índice de rugosidade, Hierarquia Fluvial (quantidade de canais e bifurcação), Índice de Circularidade; Comprimento do Rio Principal; Fato de forma; Coeficiente de manutenção; Densidade de Drenagem; Relação de bifurcação; Densidade hidrográfica; Relação de relevo; amplitude altimétrica; Sinuosidade.

Além disso, foram elaboradas cartas temáticas tais como: rede de drenagem; hierarquia fluvial; hipsométrica e clinográfica (declividades). Para confecção foi utilizado o programa QGIS e o plugin TauDEM com os algoritmos específicos. As bases cartográficas utilizadas foram as imagens SRTM disponíveis no site do INPE - TOPODATA (Folha 18_495, Folha 19_51, Folha 19_495, Folha 19_51), com o auxílio do algoritmo "Pit Remove, Flow Direction extraiu o escoamento superficial, gerando assim a rede de drenagem e a hierarquia fluvial posteriormente a este procedimento, foi utilizado o algoritmo D8 Flow Directions obtendo assim a direção de fluxos em 8 sentidos, a declividade e a hipsometria. Todas as cartas formam produzidas na escala de 1:60.000. 


\section{RESULTADOS E DISCUSSÃO}

Os principais parâmetros morfométricos utilizados para analisar a dinâmica, ou seja, a morfodinâmica de uma bacia hidrográfica. Assim, as análises foram divididas em três parâmetros, tais como, características geométricas da bacia, a rede de drenagem e morfometria do relevo.

Os parâmetros geométricos estão expressos na tabela 1, estes foram calculados para compreender melhor a característica geométrica e a morfodinâmica da bacia.

Tabela 1 Parâmetros g -eométricos da bacia hidrográfica do córrego São José-MG

\begin{tabular}{cc}
\hline $\begin{array}{c}\text { Dados obtidos } \\
\text { 2012 }\end{array}$ & $\begin{array}{c}\text { Resultados/Unidades de } \\
\text { medida }\end{array}$ \\
\hline Área da bacia (A) & $73.628 \mathrm{Km}^{2}$ \\
Perímetro (P) & $38,958 \mathrm{Km}$ \\
Comprimento axial (sentido Norte-Sul & $11,7 \mathrm{Km}$ \\
Comprimento do Canal principal - Córrego & $13,2 \mathrm{Km}$ \\
São José & dendrítico \\
Padrão de drenagem & $4^{\mathrm{a}}$ ordem \\
Hierarquia fluvial & 0,42 \\
Fator forma & $8,78 \mathrm{~km}$ \\
Largura da bacia & 89 \\
Número de nascentes & 108 \\
Número de canais & 0,61 \\
Índice de circularidade & 0,42 \\
Fator forma &
\end{tabular}

Elaboração: Autores (2019)

As informações derivadas dos parâmetros morfométricos ou associadas a outros procedimentos metodológicos são de grande valia para o planejamento urbano e a gestão ambiental. Pesquisas voltadas a essa temática podem ajudar no ordenamento territorial, na medida em que fornecem informações e dados importantíssimos para o conhecimento dos sistemas em questão e dão subsídio para um melhor direcionamento das ações de planejamento, servindo como ponto de partida para a definição e elaboração de indicadores ambientais.

A bacia hidrográfica do córrego São José é uma das principais bacias do município de Ituiutaba-MG, onde foi instalado o primeiro núcleo urbano que deu origem ao município. A partir da identificação do divisor de água principal e suas ramificações foi possível delimitar a bacia e extrair diferentes dados geométricos que contribuíram para sua caracterização.

O primeiro se refere a área da bacia que possui $74.3 \mathrm{Km}^{2}$, com um perímetro de $56,4 \mathrm{Km}$, sendo considerada como uma bacia de médio porte no município. Seguindo os critérios apontados por Torres e Machado (2012) para se identificar o canal principal de uma bacia, foram analisados os comprimentos dos cursos d'água, desde a desembocadura até a nascente mais distante, medido como a soma dos comprimentos dos seus ligamentos. Partido desta premissa o córrego que possui maior comprimento foi o córrego São José, apresentando 13,2 km de extensão. Além do córrego São José a bacia é formada por mais dois canais que chamam a atenção, sendo o córrego Pirapitinga e do Carmo. Estes, por sua vez, tributários do rio Tijuco, que deságua no rio da Prata (Figura 2).

O córrego São José possui grande parte das nascentes na área rural, cuja a principal encontra-se a aproximadamente a 652 metros de altitude e sua foz a 491 metros de altitude, possuindo uma amplitude de 161 metros, sendo o nível de base da bacia o Rio Tijuco. O canal principal foi alvo de inúmeras transformações de origem antrópica, sendo parte de seu curso canalizado, possuindo um trecho com 
canalização fechada e outro aberta, mais precisamente, o leito maior foi totalmente impermeabilizado nesse trecho canalizado, onde foi construída a Avenida José João Dib que ocupa o leito maior do canal.

O segundo córrego presente na bacia é o Pirapitinga assim como o córrego São José, também possui sua nascente na zona rural com altitude aproximada de 658 metros e o exutório encontrado a 527 metros, com amplitude de 131 metros com extensão de $8,25 \mathrm{~km}$ da desembocando no córrego do Carmo. Este canal fluvial possui dois trechos que passaram por um processo intenso de alteração na morfologia, o primeiro trecho com alteração mais recente fica nas proximidades do Centro Turístico Camilo Chaves, popularmente conhecido como o "Lago". Nesse local foi construído um aterro sobre o córrego, sendo edificado parte da Avenida Minas Gerais, que liga os bairros Natal e Novo Tempo 2. O projeto tinha como um dos objetivos, realizar a construção de um lago artificial contemplando assim um complexo turístico com áreas de prática de esporte, parque infantil, quadras poliesportivas, pistas de caminhada etc.

Figura 2 - Carta dos canais principais e extensão do canal-nascente e maior largura

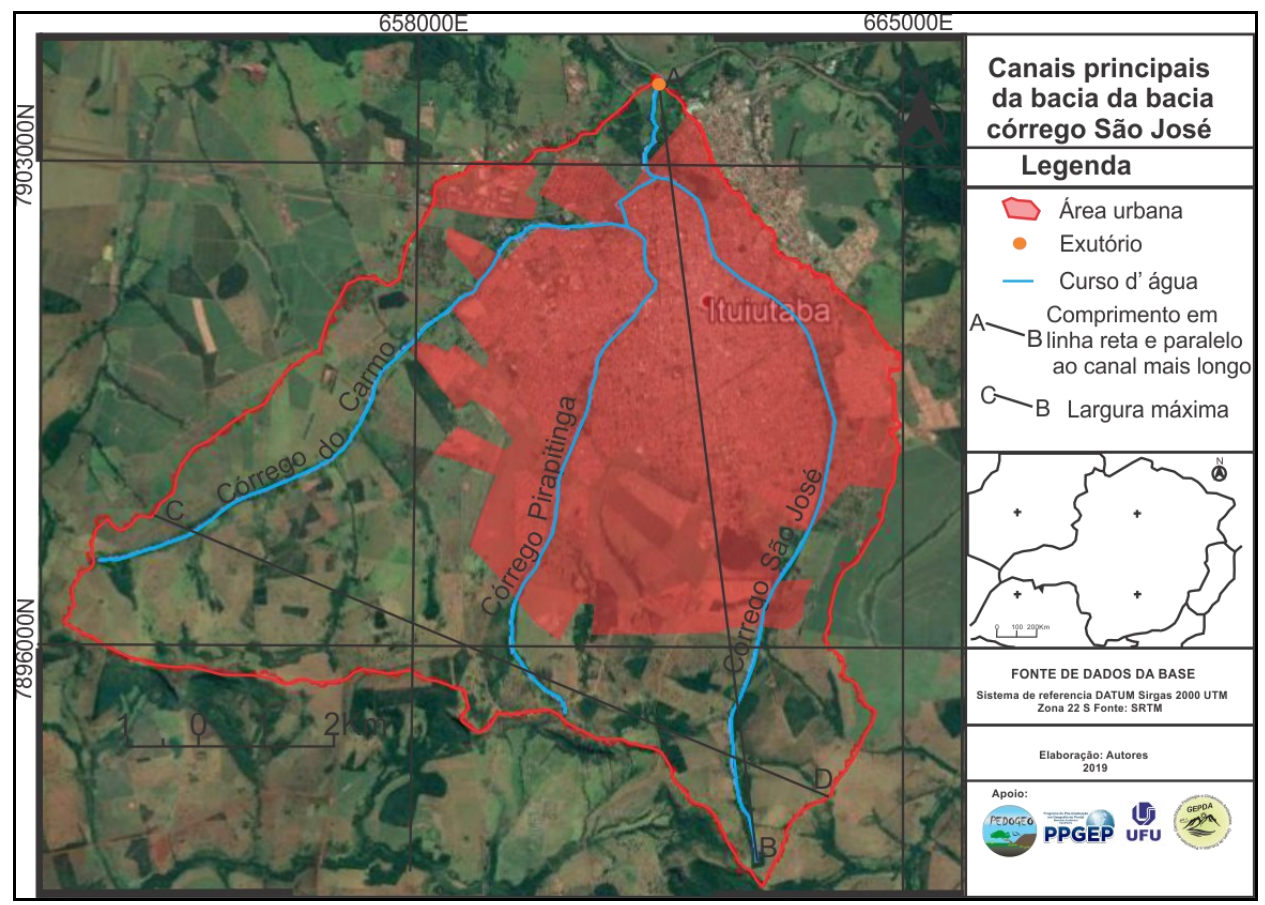

Elaboração: Autores (2019)

Outro canal fluvial importante é o córrego do Carmo, cujas nascentes principais encontram-se na área rural, sendo a principal situada a 608 metros de altitude com o exutório encontrado a 513 metros, com uma amplitude de 95 metros de diferença e possui $11,2 \mathrm{~km}$ de extensão. Diferente dos outros dois canais, grande parte da sua extensão percorre a área rural. Devido a este aspecto, a instabilidade neste canal é produzida pela ação antrópica advindas das práticas agricultura e agropecuária.

O padrão de drenagem da bacia é do tipo dendrítico (Figura 3), sendo também identificado por alguns pesquisadores como arborescente, por ser semelhante a uma árvore, apresentando-se como um padrão que se desenvolve sobre estruturas rochosas de resistência uniforme ou em estruturas sedimentares horizontalmente distribuídas (CHRISTOFOLETTI, 1980). Definição que está compatível com as estruturas geológicas encontrada na bacia, por se tratar do Grupo Bauru (Formação Adamantina ou Rio do Peixe, Formação Marília) e Grupo São Bento (Formação Serra Geral).

Analisando o tipo de substrato rochoso da bacia e o comportamento e forma dos canais fluviais foi possível classificá-la como uma bacia de $4^{\circ}$ ordem (Figura 3 ), o que demonstra ser medianamente ramificada, com um ineficaz sistema de drenagem de acordo com critérios de Strahler (1957), pois estabelece que quanto mais ramificada a rede hidrográfica da bacia, mais eficiente será o sistema de drenagem. 
O comprimento axial da bacia foi de $11,7 \mathrm{Km}$, no sentido norte-sul da bacia, ou seja, este foi medido em linha reta, desde o exutório até a nascente mais a montante da bacia, no sentido norte-sul, ou seja, o comprimento (Figura 2, seguimento A-B). Também foi possível obter o valor da largura da bacia que corresponde aproximadamente ao médio curso, no sentido leste-oeste que foi $11,7 \mathrm{~km}$. Este foi medido em linha reta identificando a maior distância observada entre os divisores de água da bacia, ou seja, a maior largura (Figura 2, seguimento C-D).

Figura 3 - Padrão de drenagem e hierarquia fluvial

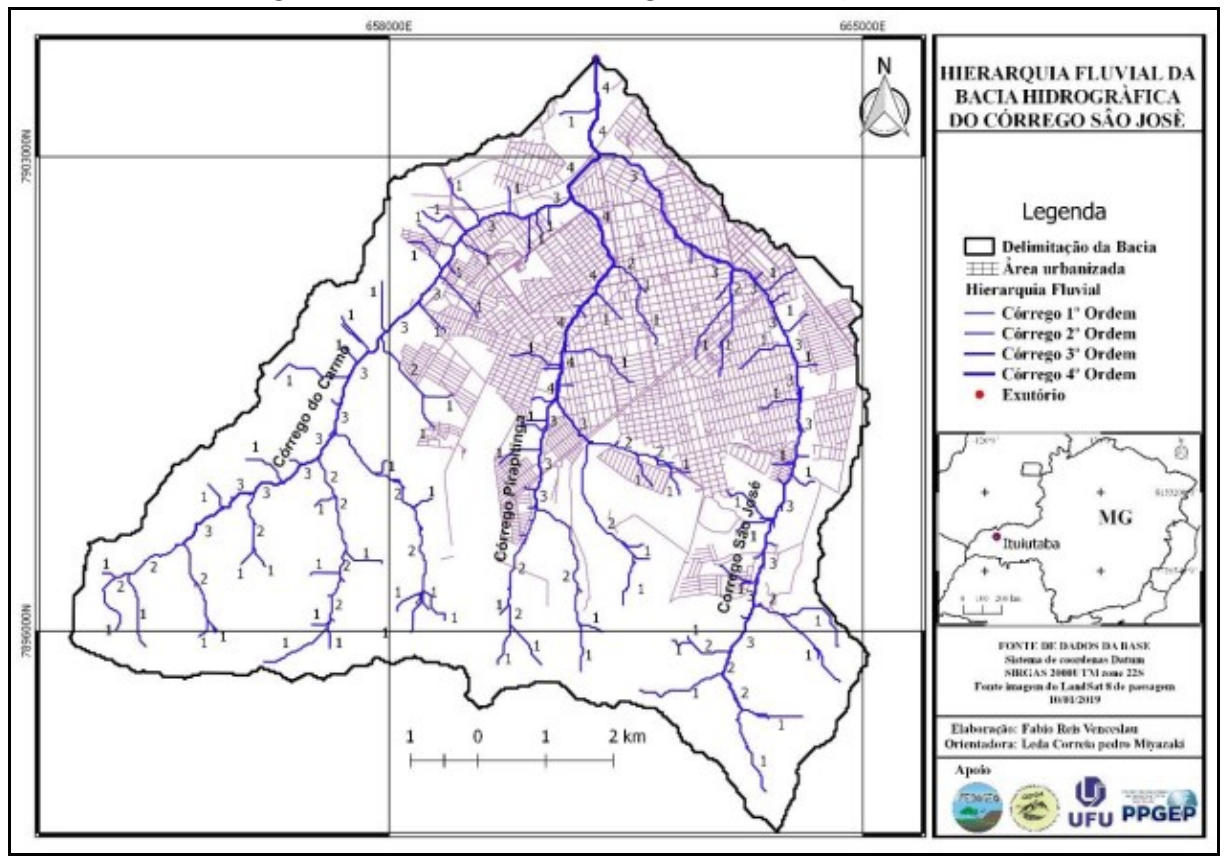

Elaboração: Autores (2019)

Para determinar a quantidade de canais na bacia foi adotado o modelo de Strahler (1952), cuja bacia apresentou 89 canais de $1^{\mathrm{a}}$ ordem, 14 de $2^{\mathrm{a}}$ ordem, 4 de $3^{\mathrm{a}}$ ordem e o canal principal de $4^{\mathrm{a}}$ ordem (Tabela 2).

Tabela 2. Quantidade de rios na bacia hidrográfica do córrego São José - MG

\begin{tabular}{cc}
\hline Ordem & Strahler (1952) \\
\hline $1^{\mathrm{a}}$ & 89 \\
$2^{\mathrm{a}}$ & 14 \\
$3^{\mathrm{a}}$ & 4 \\
$4^{\mathrm{a}}$ & 1 \\
\hline \multicolumn{3}{c}{ Total de rio da bacia = 89 } \\
\hline
\end{tabular}

Ressaltando que os canais perenes e intermitentes foram considerados dentro deste universo. O Fator de Forma (F) relaciona a forma da bacia com a de um retângulo, que corresponde a razão entre a largura média e o comprimento axial da bacia (da foz ao ponto mais longínquo do espigão), sendo calculado a partir da seguinte expressão:

$$
\mathrm{F}=\mathrm{A} / \mathrm{L}^{2}
$$

Onde $F=$ fator forma, $A=$ área de drenagem em $\left(\mathrm{km}^{2}\right), \mathrm{L}=$ comprimento do eixo da bacia $(\mathrm{Km})$.

O resultado obtido foi o valor de 0,42 , ou seja, a bacia possui tendência mediana a enchentes, tendo visto que o valor está na metade entre 0 e 1 .

$\begin{array}{llllll}\text { Caminhos de Geografia } & \text { Uberlândia-MG } & \text { v. 21, n. } 76 & \text { Ago/2020 } & \text { p. 285-305 Página } 292\end{array}$


O índice de circularidade (Kc), segundo Miller (1953, apud CHRISTOFOLETTI, 1980), indica suscetibilidade de uma bacia sofrer enchentes, isso ocorre quando o resultado for mais próximo do número 1. Esse parâmetro foi calculado pela equação:

$$
\mathrm{IC}=12,57^{*} \mathrm{~A} / \mathrm{p}^{2}
$$

Onde $\mathrm{IC}=$ é $\mathrm{o}$ índice de circularidade, $\mathrm{A}=$ área de drenagem $\left(\mathrm{Km}^{2}\right), \mathrm{P}=$ perímetro $(\mathrm{Km})$.

Este parâmetro vai de encontro com o índice de circularidade da bacia o qual deu o valor de 0,61 o que indica que a bacia possui uma forma aproximadamente redonda. A bacia circular apresenta "maior risco de provocar enchentes súbitas no canal principal quando precipitações intensas afetam toda a extensão da bacia, pois o porte de água no canal fluvial, procedente das vertentes e dos tributários, tende à simultaneidade, concentrando-se num espaço de tempo (pico de vazão ou deflúvio)" (TORRES; MACHADO, 2012, p. 60-61). Segundo Christofoletti (1980) está forma propicia um bom escoamento da água, entretanto, pode ocorrer chuvas intensas desta forma geral enchentes em determinados pontos da bacia.

Em seguida os resultados obtidos nas análises das características da rede de drenagem (Tabela 3).

Tabela 3 - Parâmetros geométricos da bacia hidrográfica do córrego São José-MG

\begin{tabular}{cc}
\hline $\begin{array}{c}\text { Dados obtidos } \\
\mathbf{2 0 1 9}\end{array}$ & $\begin{array}{c}\text { Resultados/Unidades de } \\
\text { medida }\end{array}$ \\
\hline Somatória de todos os canais $(\mathrm{Lt})$ & $97,42 \mathrm{Km}$ \\
Densidade da drenagem & $1,3 \mathrm{Km} / \mathrm{Km}^{2}$ \\
Coeficiênte de manutenção & $769,23 \mathrm{~m}^{3} \mathrm{~m}-1$ \\
Relação de bifurcação & 6,3 \\
Densidade de rio & $1,46 \mathrm{Km}^{2}$ \\
\hline
\end{tabular}

Elaboração: Autores (2019)

A somatória de todos os canais resultou em $97,42 \mathrm{Km}$ sendo que o total identificado foi de 89 canais.

O sistema de drenagem de uma bacia hidrográfica é constituído pelo canal principal, que no caso é o córrego São José e os seus afluentes, também conhecidos como tributários. O estudo da drenagem pode indicar a maior ou menor velocidade com que a água deixa a bacia hidrográfica, sendo dessa maneira , o índice que indica o grau de desenvolvimento do sistema de drenagem, ou seja, que fornece uma indicação da eficiência da drenagem da bacia, sendo expressa pela relação entre somatório dos comprimentos de todos os canais da rede de drenagem da bacia (sejam eles perenes, intermitentes ou temporários) e a área total da bacia:

$$
\mathrm{Dd}=\mathrm{L}_{\mathrm{t}} / \mathrm{A}
$$

Onde: $\mathrm{Dd}=\mathrm{a}$ densidade de drenagem $\left(\mathrm{KM} / \mathrm{Km}^{2}\right), \mathrm{Lt}=$ comprimento total de todos os canais $(\mathrm{Km}), \mathrm{A}=$ área de drenagem $\left(\mathrm{Km}^{2}\right)$.

Densidade de drenagem está relacionada como o a capacidade do canal principal em drenar a área de bacia, indiretamente pode-se obter a disponibilidade do escoamento superficial. Este parâmetro pode estar ligado com os processos erosivos, conhecendo o potencial de densidade da drenagem é possível relacionar quais as áreas que possuem maior ou menor massa volumar e assim atrelar com a saída de material (processo erosivos). Para Vilela e Matos (1975, apud TORRES; MACHADO, 2012, p. 58), "podese afirmar que um índice próximo a $5,0 \mathrm{Km} / \mathrm{Km}^{2}$ a bacia apresenta uma drenagem pobre, e $3,5 \mathrm{~km} / \mathrm{Km}^{2}$ excepcionalmente bem-drenada". Assim, o resultado obtido corresponde $1,3 \mathrm{~km} / \mathrm{km}^{2}$, este valor segundo Beltrame (1994) classifica como uma bacia muito bem drenada. 
O coeficiente de manutenção está relacionado com a área mínima necessária para a manutenção de um metro de canal de escoamento (SCHUM, 1956, apud CHRISTOFOLETTI, 1980).

$$
\mathrm{Cm}=1 / \mathrm{Dd}^{*} 1000
$$

Onde $\mathrm{Cm}=$ coeficiente de manutenção, $\mathrm{Dd}=$ densidade de drenagem

Este fator pode aumentar de conforme as características do relevo, se o mesmo possuir qualidades planas isto eleva o número de canais, em relevos acidentados o escoamento superficial busca pela declividade natural, o que acaba gerando a concentração de canais de forma naturais e maior densidade de drenagem, o valor obtido aqui para a bacia foi de $769,23 \mathrm{~m}^{2} / \mathrm{m}$, indicando que, de maneira geral, essa bacia é rica em cursos d'água.

A relação de bifurcação foi definida por Horton (1945, apud CRISTOFOLETTI, 1980), como sendo a relação entre o número total de segmentos de uma certa ordem e o número total dos de ordem imediatamente superior. Acatando-se o sistema de ordenação de Strahler, verifica-se que o resultado nunca pode ser inferior a 2, sendo calculada a partir da expressão:

$$
\mathrm{Rb}=\mathrm{Nu} / \mathrm{Nu}+1
$$

Onde Nu é o número de segmentos de determinada ordem e Nu+1 = é o número de segmentos da ordem imediatamente superior.

Pode-se dizer que esse parâmetro refere a dissecação dos canais e foi calculado para os canais de segunda ordem, com resultado de 6,3 isso implica que os canais de primeira ordem possuem um grau elevado de dissecação.

A densidade do rio e um parâmetro que está relacionado com os canais de primeira ordem ou nascentes. Este parâmetro é importante para demostras a capacidade de novos canais fluviais, o valor obtido neste elemento foi de $1,46 \mathrm{~km}^{2}$.

Em relação as morfométricas do relevo obtiveram os seguintes elementos (Tabela 4).

Tabela 4 - Parâmetros geométricos da bacia hidrográfica do córrego São José-MG

\begin{tabular}{cc}
\hline Dados obtidos & $\begin{array}{c}\text { Resultados/Unidades de } \\
\text { medida }\end{array}$ \\
\hline Índice de rugosidade & 275,6 \\
Declividade & $<=3 \% \mathrm{a}>45 \%$ \\
Razão de relevo & $0,017 \mathrm{Km}$ \\
Maior altitude da bacia & $701 \mathrm{~m}$ \\
Menor altitude da bacia & $491 \mathrm{~m}$ \\
Amplitude altimétrica & $210 \mathrm{~m}$ \\
Índice de Sinuosidade & $1,3 \mathrm{Km}$
\end{tabular}

Elaboração: Autores (2019)

O Índice de rugosidade está ligado diretamente com a declividade e a densidade de drenagem. Os valores obtidos neste parâmetro estão relacionados com o potencial de erosão, o valor encontrado foi de 275,6 classificando como mediana nos aspectos de erosões.

A declividade da bacia, compreender $<=3 \%$ a $>45 \%$ graus de inclinação, as menores inclinações são encontras nos topos do relevo de colinas e altas vertentes, onde predominam as classes de $<=3 \%$ e $3-8 \%$ de declive. Já em relação as inclinações as mais declivosas encontram-se nas vertentes dos relevos 
tabuliformes, no alto curso da bacia apresentando declives superiores a $45 \%$ de inclinação, sendo a segunda classe com declividades mais acentuadas o intervalo de 8 a $20 \%$ (Figura 4).

Figura 4 - Carta Clinográfica (declividades)

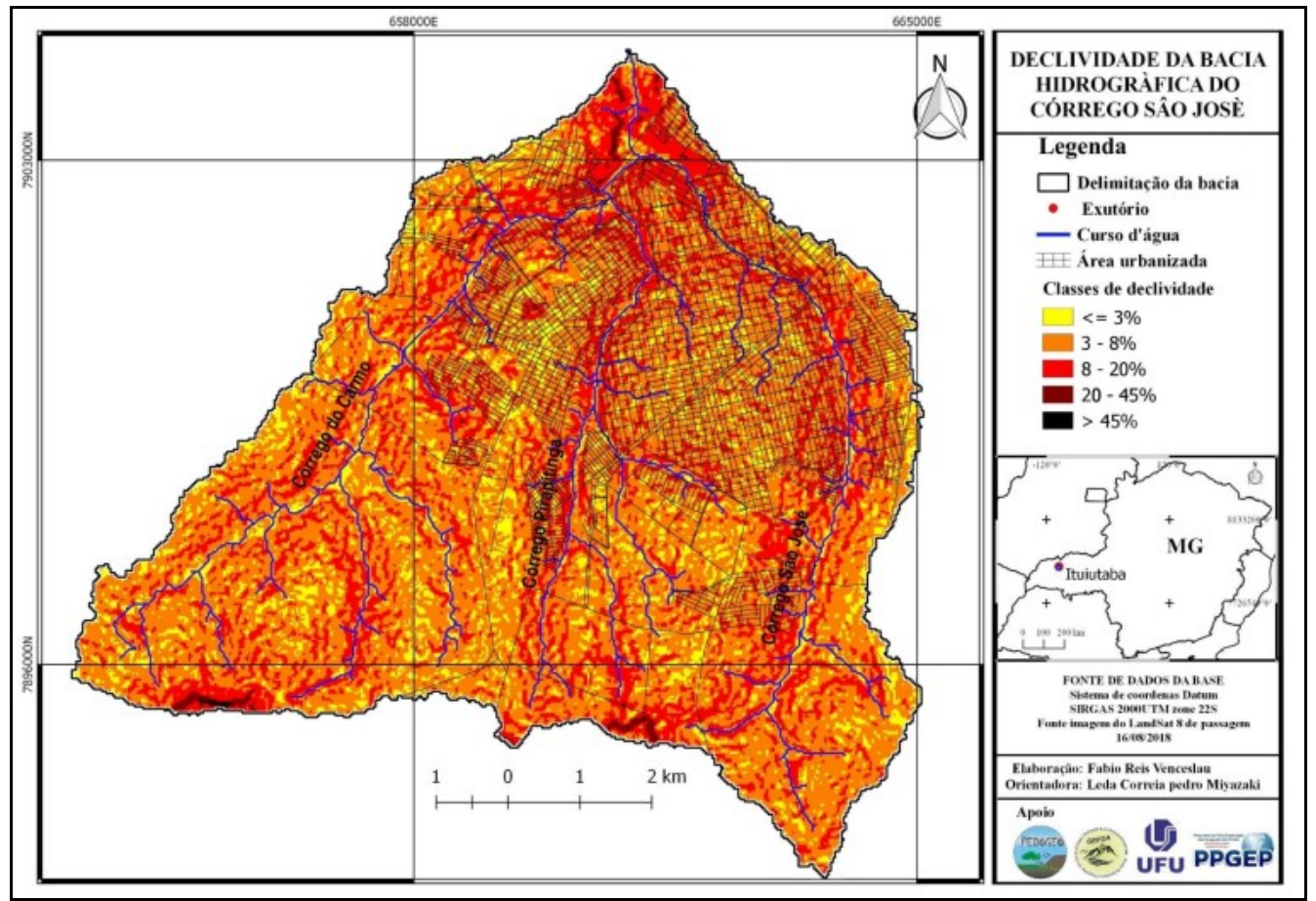

Elaboração: Autores (2019)

A razão do relevo foi analisada conforme proposição de Shumm (1956, apud MARCHETTI, 1980), a partir da relação entre a diferença de altitude dos pontos extremos da bacia ou amplitude altimétrica e o maior comprimento, que corresponde à direção do vale principal, entre a foz e o ponto extremo sobre a linha do divisor de águas.

$$
\mathrm{Rr}=\mathrm{H} / \mathrm{C}
$$

Onde $\mathrm{Rr}=$ razão do relevo, $\mathrm{H}=$ amplitude altimétrica, $\mathrm{C}=$ maior comprimento da bacia.

Assim, a bacia apresentou uma razão de relevo de $0,017 \mathrm{Km}$ demonstrando um baixo índice de razão do relevo, isso é resultado da baixa amplitude altimétrica e consequentemente uma bacia declividade média caracterizando o relevo como suave ondulado.

A menor altitude encontrada na bacia foi de 491 metros nas proximidades do exutório da bacia e a maior altitude da bacia corresponde ao valor de 701 metros, localizado no ponto mais elevado da Serra do Corpo Seco ou também conhecido como Morro São Vicente.

Para o cálculo da altitude média referente a cota máxima da bacia (máxima altitude da bacia) foi identificado os pontos mais elevados entre os canais de primeira ordem principais do trecho superior da bacia. Foi calculada a partir da média aritmética entre os valores de maior altitude observada nas cabeceiras dos principais canais e a menor altitude na foz (Tabela 5). 
Tabela 5 - Parâmetros geométricos da bacia hidrográfica do córrego São José-MG

\begin{tabular}{cccc}
\hline Pontos & Latitude & Longitude & $\begin{array}{c}\text { Cota próxima a nascente } \\
\text { principal }\end{array}$ \\
\hline Córrego Carmo & $19^{\circ} 1^{\prime} 42^{\prime \prime} \mathrm{S}$ & $49^{\circ} 31^{\prime} 7^{\prime \prime} \mathrm{O}$ & $654 \mathrm{~m}$ \\
Córrego Pirapitinga & $19^{\circ} 2^{\prime} 58^{\prime \prime} \mathrm{S}$ & $49^{\circ} 26^{\prime} 38^{\prime \prime} \mathrm{O}$ & $669 \mathrm{~m}$ \\
Córrego São José & $19^{\circ} 2^{\prime} 36^{\prime \prime} \mathrm{S}$ & $49^{\circ} 26^{\prime} 64^{\prime \prime} \mathrm{O}$ & $701 \mathrm{~m}$ \\
Foz & $18^{\circ} 56^{\prime} 46^{\prime \prime} \mathrm{S}$ & $49^{\circ} 28^{\prime} 11^{\prime \prime} \mathrm{O}$ & $491 \mathrm{~m}$ \\
& & $675 \mathrm{~m}$ \\
& & $583 \mathrm{~m}$ \\
\hline
\end{tabular}

Elaboração: Autores (2019)

A amplitude altimétrica da bacia refere-se a diferença entre a maior e a menor altitude da área da bacia e é expressa em metros, sendo aplicado a seguinte formula:

$$
\mathrm{H}=\mathrm{AM}-\mathrm{Am}
$$

Onde $\mathrm{H}=$ amplitude altimétrica, $\mathrm{AM}=$ maior altitude, $\mathrm{Am}=$ menor altitude

A altitude média da bacia é de 583 metros e sua amplitude altimétrica do relevo foi de 210 metros.

A carta hipsométrica foi elaborada a partir da definição de cinco (< 550 m, 550-600 m, 600-650 m, 650 $700 \mathrm{~m},>700 \mathrm{~m}$ ), sendo predominante a classe 550 a 600 metros, seguida da classe de 600 a 650 metros (Figura 5). Com estes dados foi possível determinar a amplitude altimétrica, os pontos mais altos e o ponto mais baixo da bacia.

Figura 5 - Carta hipsométrica

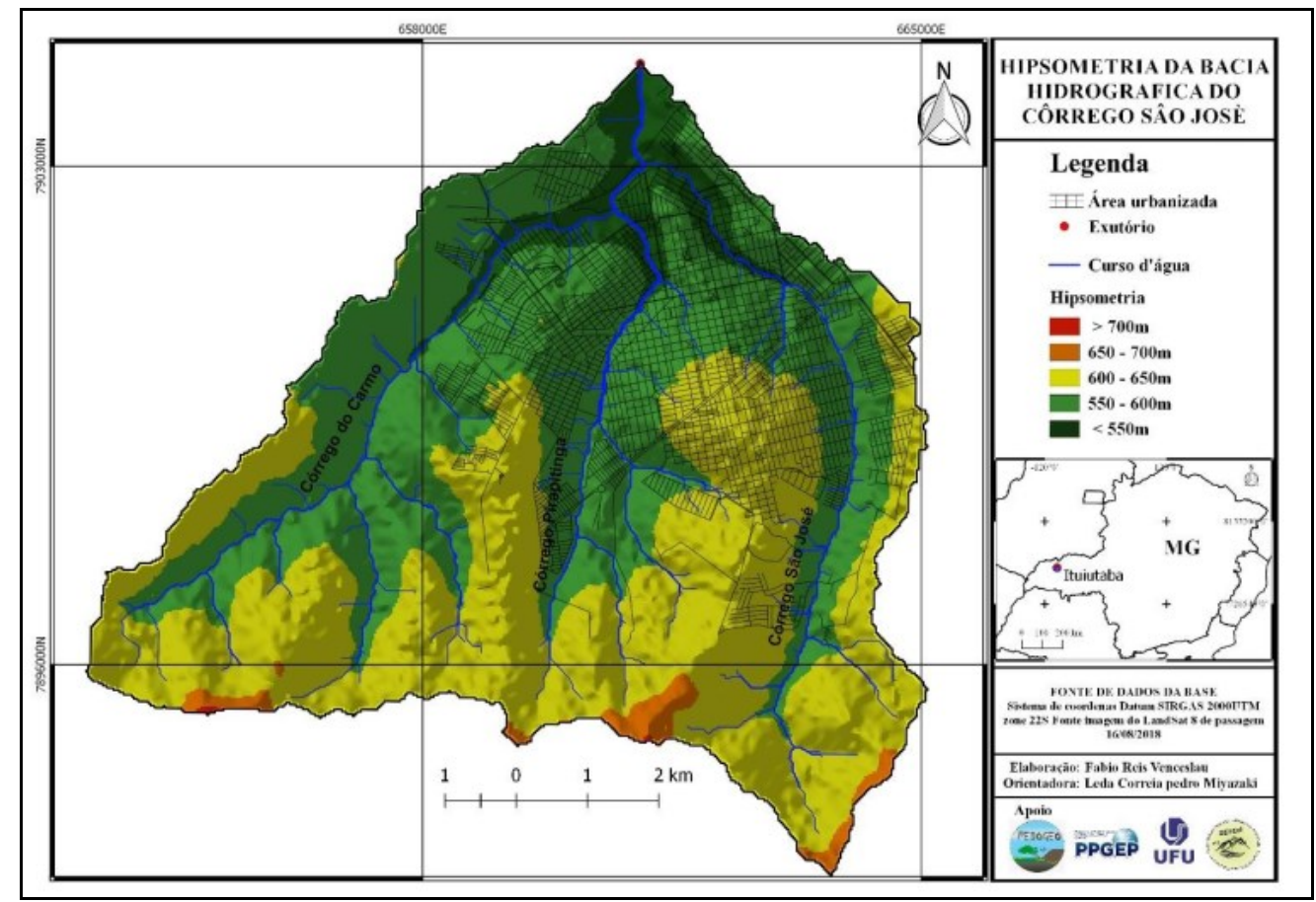

Elaboração: Autores (2019) 
As altitudes da bacia giram entrono de 500 a 700 metros em relação ao nível do mar, as baixas altitudes esta ligadas diretamente com os cursos d'água, os quais possuem altitudes de 500 metros nas proximidades da foz e altitudes mais elevadas correspondendo aproximadamente de 600 a 700 metros a montante, onde encontram-se o relevo de colinas.

Já nos topos das vertentes ao centro da bacia compreende as altitudes de 600 a 650 metros. As áreas mais elevadas estão relacionadas com as cabeceiras dos canais fluviais, local onde a existência de morros residuais ou relevos tabuliformes, com altitudes que variam entre 650 metros chegando até 750 metros.

Os resultados obtidos nos parâmetros morfométricos podem contribuir para uma análise dos processos morfodinâmicos decorrentes na bacia, tento visto que estes parâmetros estão relacionados com a capacidade de remoção, transporte e deposição de sedimento, o que ajuda na caracterização e processos atuantes na bacia, ou seja a sua morfodinâmica.

Relacionando este item com o índice de sinuosidade, tendo visto que, quanto mais sinuoso o canal maior será a sua competência para reter água na bacia. Expressa a relação entre o comprimento do canal principal e a distância vetorial entre os dois pontos extremos do canal principal, ou seja, relaciono o comprimento verdadeiro/sinuoso do canal com sua distância vetorial (em linha reta, vetor). Pode ser calculado a partir da expressão:

$$
\mathrm{Is}=\mathrm{L} / \mathrm{d} \mathrm{v}
$$

Is = índice de sinuosidade, $L$ = é o comprimento do rio principal (considerando sua sinuosidade), dv = é a distância vetorial entre os pontos extremos do canal principal.

Os valores próximos de 2,0 sugerem canais tortuosos e os valores intermediários indicam formas transicionais, regulares e irregulares. Assim, pode-se inferir que a sinuosidade dos canais é influenciada pela carga de sedimentos, pela compartimentação litológica, estruturação geológica e também pela declividade dos canais (LANA, ALVES, CASTRO, 2001). Nesse sentido, o resultado obtido foi de $1,13 \mathrm{~km}$ classificado como pouco sinuoso, os valores abaixo de 2 indica controle estrutural e acima de 2 implicam em baixa energia. Schumm (apud Guerra; Cunha; 1995), diz que a sinuosidade dos cursos d' água são determinados muito mais pelo tipo de carga detrítica do que pela descarga fluvial, onde os canais meândricos relacionam-se aos elevados teores de silte e argila e os canais anastomosados a uma carga mais arenosa, a diminuição da sinuosidade está ligada ao aumento da granulometria e da quantidade de carga detrítica.

A espacialização dos compartimentos geomorfológicos da área de estudo forneceu um material inédito bastante detalhado da bacia, pois especializou-se três importantes compartimentos do relevo que são indispensáveis para compreender a morfodinâmica da área de estudo, sendo esses os topos, as vertentes e os fundos de vale (Figura 6). Observando o relevo da bacia hidrográfica do Córrego São José é possível identificar duas formas que se destacam na paisagem, sendo o relevo de colinas suaves onduladas e os relevos tabuliformes com superfície cimeira plano em forma de mesa.

O relevo de colinas é a morfologia predominante em toda a bacia e possuem características convexas e suaves, com grau de elevação baixo não perpassando os 50 metros (Figura 7, A), estes aspectos suaves ondulado são reflexo do processo denudacional decorrente do tempo geológico. Um fator que contribuiu para esta forma está ligado a litologia da área que apresentam rochas sedimentares da Formação Vale do Rio do Peixe, conhecida anteriorente como Formação Adamantina, sendo bastante friáveis ao processo de denudação 
Figura 6 - Compartimentação geomorfológica da bacia hidrográfica do córrego São José

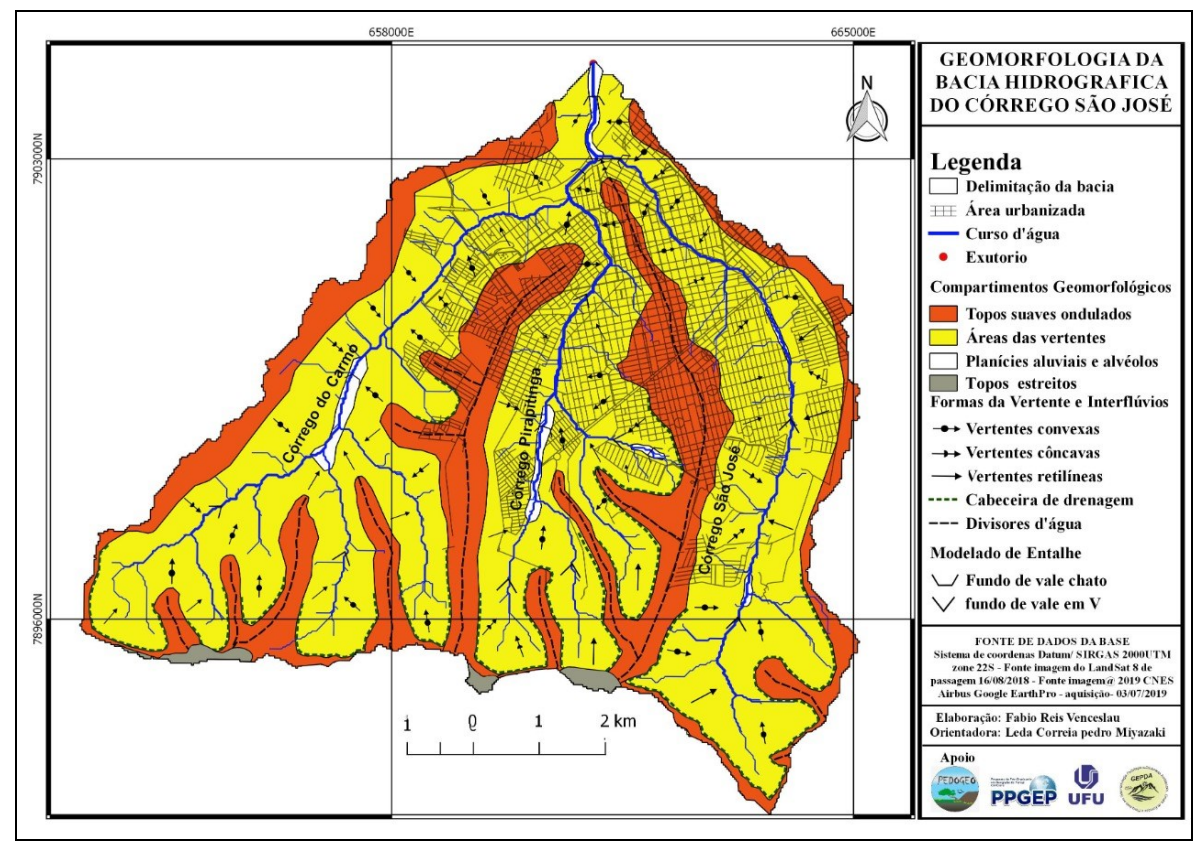

Elaboração: Autores (2019)

Nas partes onde se localiza as cabeceiras dos canais fluviais, estão presentes os relevos residuais conhecidos como tabuliformes. Esse relevo possui uma superfície bastante plana, com vertentes que possuem declividades acentuadas, cuja a aparência é no formato de uma mesa. Este tipo de forma de relevo da bacia foi denominado por Pedro Miyazaki (2017) como relevos residuais do tipo tabuliformes sendo considerado como áreas que resistiram ao intenso processo de denudação devido a constituição litológica, arenitos da Formação Marília (Figura 7B).

Figura 7 - A- Relevo de Colinas com topo suavemente convexo (representada pela linha amarela) e drenagem dos cursos d'água (azuis) da bacia hidrográfica. B- Relvo residual do tipo tabuliforme - Serra do Corpo Seco - Alto curso da bacia

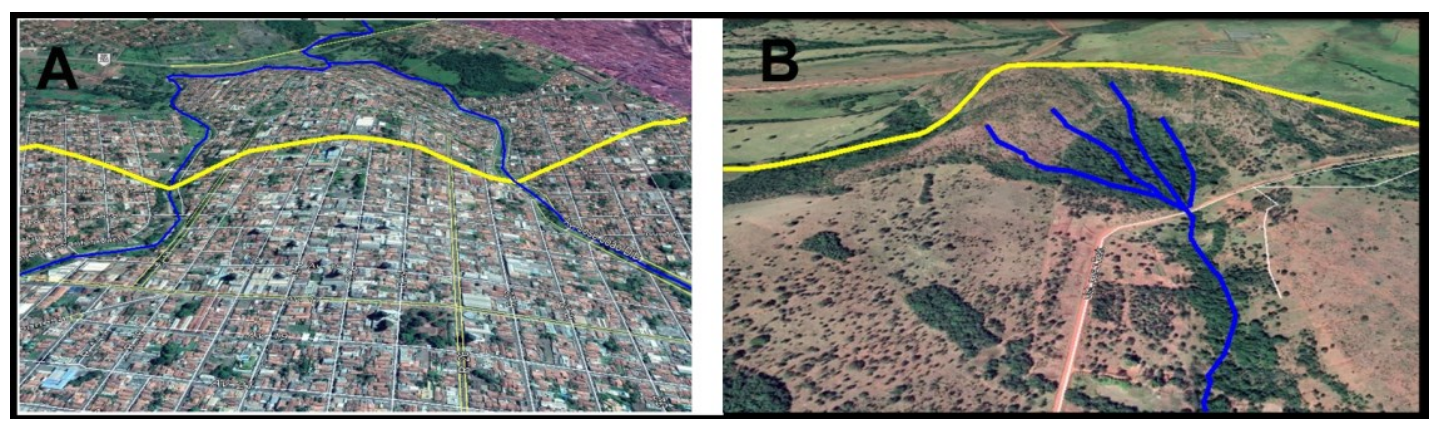

Fonte: Autores (2019)

Os residuais do tipo tabuliformes configura o segundo tipo de relevo, estão presentes nas áreas mais altas da bacia, onde se encontram as nascentes, são áreas que se destacam na paisagem como feições semelhantes a mesa, possuindo topo plano e vertentes íngremes. Os topos do relevo 
tabuliforme ou também chamados de residuais são planos como áreas alongados e estreitos formando assim parte do divisor de água da bacia. Destacando os aspectos de cunho morfoestrutural os residuais possuem estrutura plana-paralela, camadas horizontais com leve inclinação subhorizontal as rochas do tipo sedimentares existente nestas estruturas apresentam na sua composição alternância na sua resistência. Com a elaboração do mapeamento dos compartimentos geomorfológicos da bacia foi possível descrever quatro áreas, sendo estas: a) As áreas de topos amplos suavemente ondulados das colinas convexas, b) Área das vertentes côncavas, convexas e retilíneas, c) Áreas das planícies aluviais e alvéolos, d) Áreas dos topos estreitos suaves e ondulados dos relevos residuais do tipo tabuliforme.

\section{a) Áreas dos topos amplos suavemente ondulados das colinas convexadas}

Esta área se apresenta em grandes parcela na bacia, os topos suaves e ondulados e distinguir-se por apresentar feições de espigões divisores de água ramificados (representados na carta com tracejado de cor preta), um aspectos importante deste domino é o fator de divisor de água para os principais canais da bacia dividindo as águas para as principais bacias hidrográficas na área urbana, sendo estas (Figura $8 \mathrm{~A}$ ).

\section{b) Área das vertentes côncavas, convexas e retilíneas}

As áreas que constituem o compartimento das vertentes se identificaram três formas, as vertentes côncavas, as convexas e as retilíneas. Estas formas possuem atributos diferentes na vertente de acordo com a sua morfologia, as vertentes côncavas são capazes de concentrar as águas pluviais chegando a produzir pequenas erosões como sulcos e contribuir para o escoamento difuso. As vertentes convexas devido a sua forma possibilitam a dispersão das águas pluviais, isto gera um fator de acúmulo da água nestas vertentes, favorecendo a infiltração. Já as vertentes retilíneas em locais com grandes extensões propiciam o escoamento superficial, este aspecto pode dar origem as formas erosivas lineares na vertente (Figura $8 \mathrm{~B}$ ).

\section{c) $A$ área das planícies aluviais e alvéolos}

$\mathrm{Na}$ bacia esta área pode ser identificada nos fundos de vales onde se estendem tanto as planícies aluviais com morfologias de vale em berço, e também em formato de $V$, estas singularidade facilita a retificação e canalização, gerando instabilidade a dinâmica fluvial nos cursos d'água, a construção de vias urbanas em áreas de planícies de inundação impermeabiliza o solo, esta ação dificulta a infiltração da água no solo e facilita o escoamento superficial, ocasionando erosões ao longo da vertente (Figura $8 \mathrm{C}$ ).

\section{d) Áreas dos topos estreitos suaves e ondulados dos relevos residuais do tipo tabuliforme}

Esta área compõem o último compartimento geomorfológico descritos na bacia onde são encontrados os relevos residuais mais elevados, estando associados as nascentes dos canais fluviais e as atividades rurais (Figura $8 \mathrm{E}$ ). As vertentes desse relevo residual possuem rampas de colúvios (Figura $8 \mathrm{~F}$ ), consideradas como depósitos de sedimentos que passaram pelo processo de intemperismo e foram lixiviados pela ação gravitacional, consolidado como material depositado ou de deposição não recente. Este material tem característica heterogêneo com presença de vegetal. $E$ outras vertentes bastante escarpadas com rochas aflorantes, onde se encontram alguns depósitos de tálus. Outro aspecto identificado nessas vertentes abruptas são as estruturas em camadas plano-paralelo, indicativo de alternância da resistência litológica da Formação Marília, destaca-se as cornijas. 
Figura 8 - A- Áreas dos topos amplos suavemente ondulados das colinas convexadas localizada no alto curso da bacia; B- Área com perfil de uma vertente retilínea localizada no médio curso da bacia; C-

Morfologia das vertentes côncavas, convexas e retilíneas; D- Morfologia de fundo de vale de uma planície aluvial localizada no médio curso do São José; E- Relevo residual do tipo tabuliforme da Serra do Corpo Seco; F- Rampas de colúvio localizado na Serra do Corpo Seco

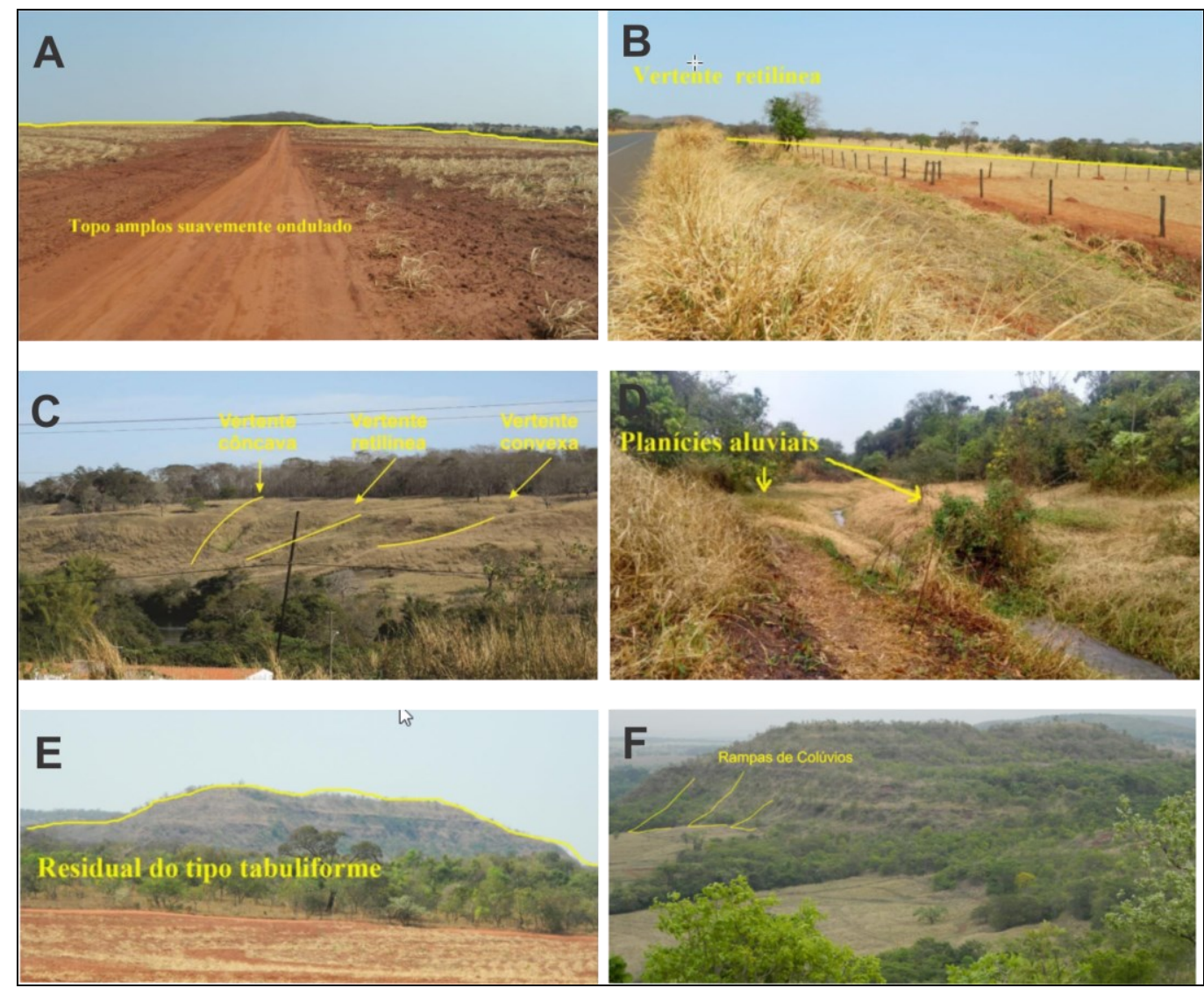

Fonte: Autores (2019)

\section{Processos morfodinâmicos e seus registros na paisagem}

Os parâmetros geomorfométricos indicaram que a bacia hidrográfica do córrego São José apresenta um predomínio de baixas altitudes e baixa amplitude altimétrica, além de declividades não muito acentuadas no geral. A forma circular indica que a bacia tem uma tendência a sofrer enchentes em determinados pontos quando ocorrem as chuvas intensas. Pode ser considerada como uma bacia de médio porte, em relação ao município, apresenta um padrão de drenagem dendrítico e é classificado como $4^{\mathrm{a}}$ ordem, sendo medianamente ramificada demonstrando um eficaz sistema de drenagem. A densidade de drenagem indicou uma alta drenabilidade sendo um parâmetro importante para se retratar a morfodinâmica da bacia e características do relevo, apresentando uma drenagem bem desenvolvida, medianamente dissecado e maior capacidade de remoção de sedimentos.

Esses aspectos contribuem para o entendimento de algumas características físicas e subsidiam o entendimento da morfodinâmica local, além de permitir compreender como a relação sociedade e natureza pode interferir diretamente na dinâmica de escoamento, infiltração, enchentes, inundação, erosão na bacia.

A dinâmica da sociedade aqui analisada foi representada pela ocupação da bacia realizada pelo ser humano, onde a área urbana é resultado da ação antrópica diretamente no relevo (esculturando-o) e por meio da impermeabilização do solo (edificando-o).

Segundo Pedro Miyazaki e Nunes (2012, p. 82), os desastres naturais assim como alguns processos naturais "são agravados e intensificados pelo ser humano, que tanto induz como também acelera os 
processos naturais. Diante disso, os efeitos acabam sendo impactantes, tanto para a população ocupante da área afetada, quanto para a própria natureza (solo, rocha, rios, vegetação etc.)".

Pensando nessa premissa, três exemplos de processos morfodinâmicos que foram acelerados/intensificados na bacia estão relacionados a dinâmica de escoamento superficial e fluvial, deixando marcas na paisagem em forma de feições erosivas, banco de sedimentos (assoreamentos) nos canais fluviais e episódios de alagamentos.

Essa aceleração/intensificação dos processos morfodinâmicos podem ser entendidos a partir da forma como o relevo foi apropriado e ocupado, o que gerou a esculturação das vertentes, a impermeabilização de grande parte das áreas de topos, vertentes e fundos de vale do relevo de colinas.

Desde os primórdios do processo de apropriação e ocupação do relevo, que gerou o primeiro "núcleo urbano" do município de Ituiutaba a ocupação esculturou inicialmente as áreas de topos das colinas, cuja expansão territorial urbana foi se direcionando e impermeabilizando cada vez mais as áreas de topos (seguindo os divisores de águas), vertentes e consequentemente os fundos de vale e atualmente ocupa grande parte do baixo e médio curso da bacia. Devido a isso, o sítio urbano se encontra historicamente recortado por três canais principais e vários cursos d'água de pequena extensão e canais de escoamento que compõem a rede de drenagem bacia hidrográfica do córrego São José, sendo esses os córregos São José, Pirapitinga e do Carmo.

O processo de apropriação e consequentemente a ocupação do relevo, onde foi implantado o primeiro núcleo que deu origem ao município de Ituiutaba, se iniciou em por volta de 1820 quando foi construída a primeira capela dedicada a São José do Tijuco. A capela foi construída no topo do relevo de colina, exatamente no divisor de águas das bacias do córrego Pirapitinga e São José, ou conhecido na época como córrego Sujo. A implantação do núcleo que deu origem a cidade de Ituiutaba ocorreu a partir da doação de terras feita por Joaquim Antônio de Morais, onde existia a fazenda do Carmo e José da Silva Ramos, que era dono da fazenda São Lourenço (BARBOSA, 1996).

A criação oficial do núcleo que deu origem a cidade de Ituiutaba ocorreu somente em 1839, quando o povoado de São José do Tijuco foi elevado à condição de município. Em 16 de setembro de 1901, foi desmembrado do município de Prata e categorizado como Vila Platina, tornando-se um município independente. A vila foi elevada a condição de cidade em no ano de 1915, recebendo o nome de Ituiutaba (BARBOSA, 1995; OLIVEIRA, 2013). Desde então, a ocupação do relevo se expandiu para as vertentes e fundos de vale dos córregos São José e Pirapitinga.

Desde então, os cursos d'águas que constituem a rede drenagem da bacia do Córrego São José, foram incorporados ao tecido urbano e atualmente apresentam problemas ambientais sérios, devido as formas de ocupação e as políticas de urbanização que ocorreram nos fundos de vale.

Esses fundos de vales, juntamente com os canais fluviais foram retificados, canalizados (fechada e/ou aberta), além da ocupação das áreas onde se encontram as planícies aluviais ou de inundação para a construção de ruas e avenidas entre outras. Isso provocou um rompimento do equilíbrio dinâmico dos processos naturais, afetando a morfodinâmica da bacia, principalmente em relação a diminuição da infiltração das águas pluviais e o aumento e a concentração do escoamento superficial nas áreas de topo, vertentes e fundos de vale do relevo de colinas, de forma concentrada e canalizada em determinadas ruas.

O resultado disso, foi a manifestação de impactos socioambientais, tais como as erosões, que provocaram a perda de solo e consequentemente o assoreamento dos canais fluviais e a geração de alagamentos oriundos da ineficiência ou ausência do sistema de drenagem das águas superficiais da área urbana

A formação das erosões urbanas identificadas tivera origem ligada principalmente ao escoamento superficial concentrado, pois a impermeabilização dos terrenos e a construções de ruas seguindo o comprimento de rampa suave e alongado das vertentes direcionaram o fluxo de águas pluviais para determinadas ruas. Com a morfologia do comprimento de rampa das vertentes sendo suave e alongado favoreceu ao escoamento concentrado e acelerado, que ao atingir as baixas vertentes e os fundos de vale promoveram a remoção do solo, provocando incisões lineares em forma de sulcos, ravinas e voçorocas (Figura 9). A formação das erosões rurais tem origem não só na forma como o relevo foi apropriado e ocupado, mas sobretudo, no manejo do solo. 
Figura 9 - A- Erosão linear localizada na baixa vertente e fundo de vale do córrego Pirapitinga, em forma de voçoroca que foi provocada pelo escoamento superficial concentrado. É possível verificar que a erosão possui vários tipos de resíduos sólidos, resultante da tentativa do poder público em conter a erosão com o preenchimento de resíduos sólidos (ponto de vista da imagem de dentro da erosão). B- A mesma voçoroca observada da cabeira da erosão, possuindo naquele momento aproximadamente 7 metros de profundidade.

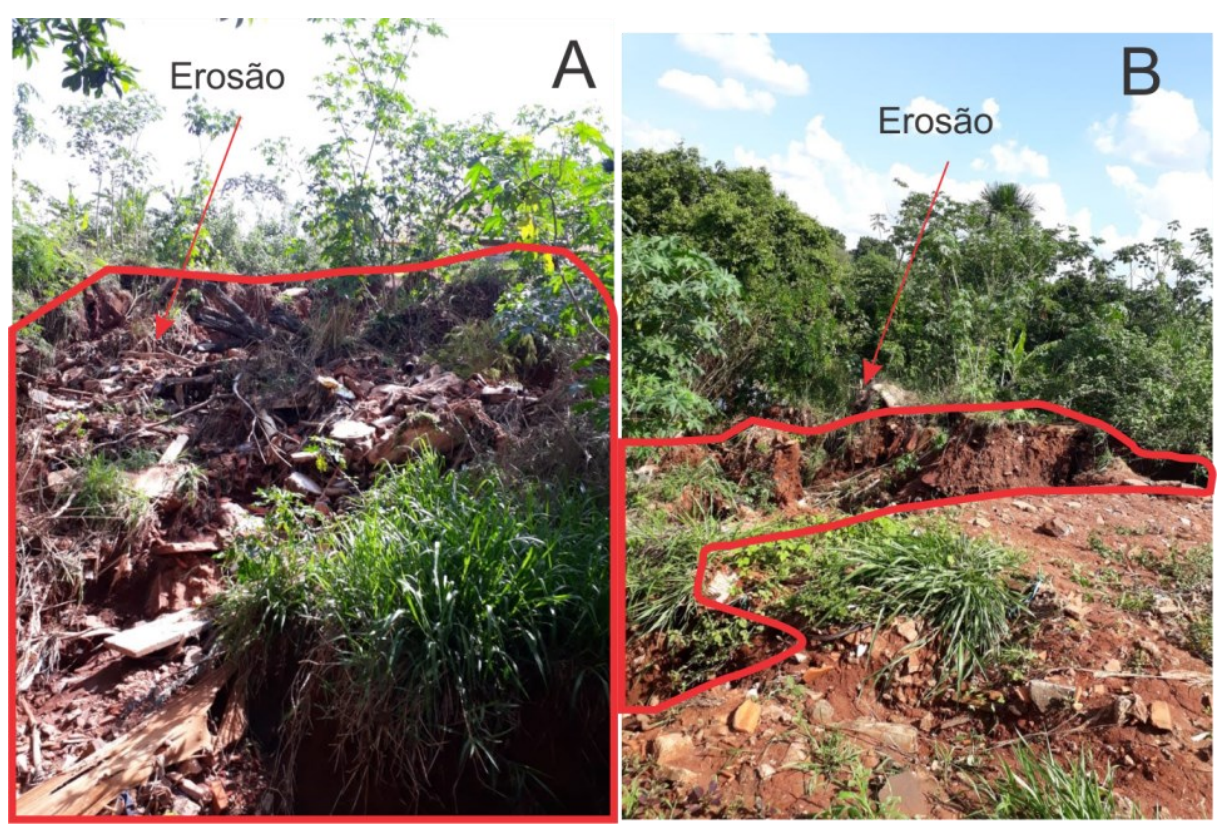

Fonte: Autores (2019)

As práticas agrícolas e a pecuária existente no médio e alto curso da bacia associada a ausência de práticas mecânicas e edáficas de conservação do solo provocaram a retirada da cobertura vegetal existente, o revolvimento cada vez mais do horizonte A do solo e a concentração dos fluxos de águas pluviais em determinados locais no relevo, geraram incisões lineares (sulcos, ravinas e voçorocas) e erosão laminar na área rural da bacia, sendo bastante significativo para a intensificação do processo de degradação.

Outro impacto encontrado tanto na área urbana quanto na área rural da bacia são os bancos de areia, ou seja, o assoreamento dos canais fluviais. Essas práticas supracitadas provocaram o assoreamento nos canais fluviais (Figura 10), pois com o solo desprotegido e a ausência de práticas mecânicas e edáficas de conservação do solo nas áreas rurais e as práticas de retirada da cobertura vegetal associado aos processos de terraplanagem nas áreas urbanas, desprenderam partículas do solo, que posteriormente foram carreadas e depositadas nos fundos de vale, onde encontram-se os canais fluviais da bacia. Isso contribuiu para a formação de vários bancos de sedimentos ao longo dos canais fluviais dos córregos São José, Pirapitinga e Carmo. 
Figura 10 - A- banco de areia (assoreamento) canal fluvial do córrego Pirapitinga, é possível verificar que há o predomínio de resto de materiais de construção, ou seja, entulho dentro do canal, juntamente com resíduos sólidos. Isso se formou devido ao material que foi colocado dentro de uma voçoroca localizado na baixa vertente e fundo de vale do córrego Pirapitinga, que no período de chuva, as águas oriundas do escoamento superficial provocaram novamente o entalhamento no local onde havia a erosão. B- banco de areia formada por sedimentos que foram transportados ao longo do canal e depositados no baixo curso do rio Pirapitinga.

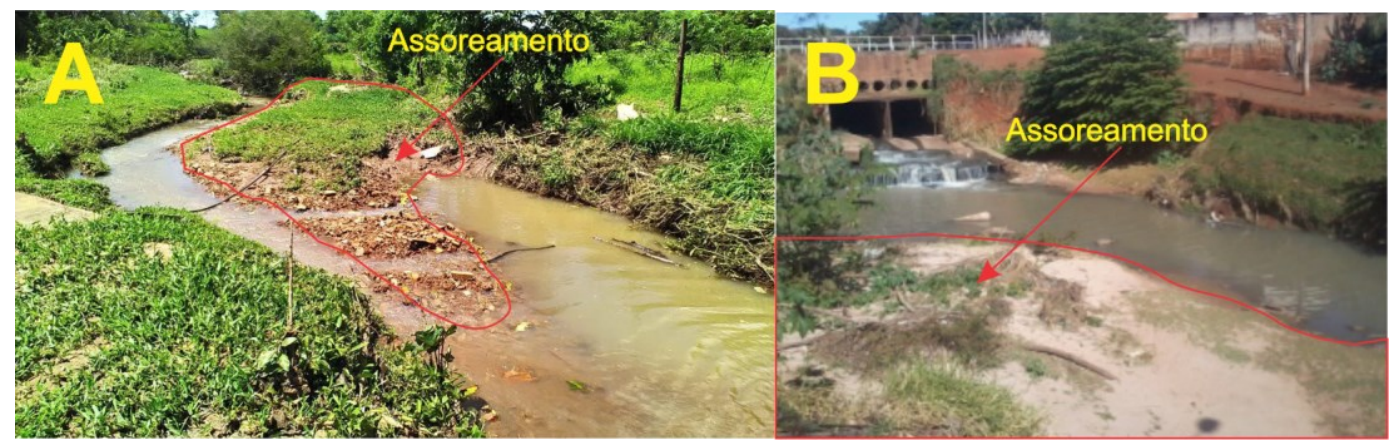

Autores (2019)

Os episódios de alagamentos são exclusivos da área urbana, sendo resultado da ação antrópica que ao ocupar o relevo em um primeiro momento retira toda a cobertura vegetal, deixando o solo exposto, depois retifica os topos e as vertentes por meio do processo de terraplanagem (com a construção de talude e aterros) para deixar os lotes ou terrenos cada vez mais planos. Em um segundo momento o processo de ocupação interfere diretamente na infiltração das águas pluviais, uma vez que grande parte das águas da chuva passa a escoar superficialmente em relação a infiltração, concentrando-se em determinados locais. Associado a isso tem-se a ineficiência do sistema de drenagem urbano que não consegue escoar toda a água que chega nas vertentes e nos fundos de vale, provocando pontos de alagamentos (Figura 11).

Figura 11 - A- Ação da água no fundo de vale do córrego São José, onde foram derrubadas algumas árvores no local. B. Alagamento da avenida José João Dib trecho do córrego São José que foi retificado, canalizado e cuja a planície de inundação foi ocupada pela avenida.

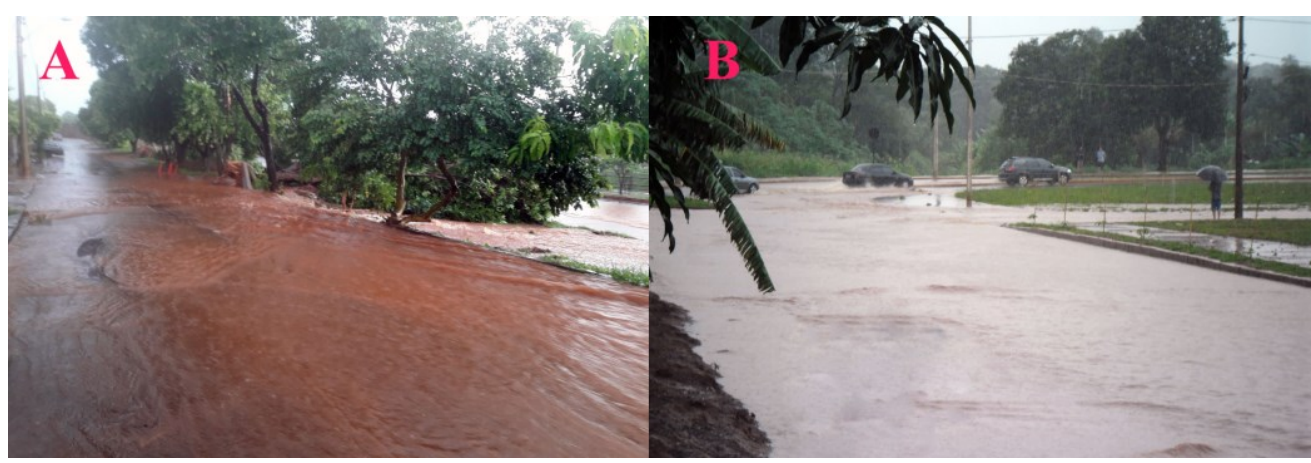

Fonte: Autores (2019)

Esses foram os principais registros de processos morfodinâmicos que foram intensificados pela ação humana e que provocaram o rompimento do equilíbrio dinâmico desses processos considerados naturais na área de estudo, que exemplificam alguns dos principais impactos socioambientais encontrados no município. 


\section{CONSIDERAÇÕES FINAIS}

A pesquisa demonstrou por meio da análise geomorfométrica que a área de estudo é bem drenada e com bastantes canais fluviais, apresenta um baixo índice de sinuosidade dos cursos d'água o que indicou um controle estrutural. Foi possível concluir que a bacia apresenta uma pequena amplitude altimétrica, resultando em um índice de declividade pouco expressivo, o que indica um relevo mais suave e com poucos problemas relacionados aos movimentos de massa do tipo rotacional e translacional. A bacia possui um Fator de Forma e Índice de circularidade medianos, demonstrando que tem uma forma mais arredondada, o que aponta uma susceptibilidade a ocorrência de enchentes em períodos de chuva. A densidade de drenagem demonstrou que o canal principal tem uma ótima capacidade de drenar a área da bacia, apresentando-se bem dissecado com canais fluviais de primeira ordem mais encaixados, isso indica que essas áreas a montante possuem maior massa volumar de saída de material (erodindo o relevo) e a jusante onde encontram-se assentados os materiais que foram desprendidos, transportados e depositados (formando os banco de sedimentos ou assoreamento).

No geral, o estudo quantitativo da bacia, que considerou apenas os aspectos naturais foi capaz de demonstrar que os índices geomorfométricos evidenciaram uma tendência mediana a ocorrência de enchentes que poderá ocorrer com mais intensidade no canal principal da bacia em períodos de chuvas intensas e constantes e que há uma suceptibilidade erosiva nos canais a montante (com a presença de canais mais encaixados no leito rochoso) e deposicional a jusante.

A partir do estudo da geomorfometria (considera as análises quantitativas dos aspectos naturais) relacionado a morfodinâmica da paisagem (considerando os processos naturais e a ação humano), que envolveu a bacia hidrográfica do córrego São José, foi possível verificar que o compartimento geomorfológico dos fundos de vale são os que mais concentram os impactos socioambientais, sendo exemplificados por meio das erosões, os assoreamentos e os episódios de alagamentos. Isso é decorrente da forma como o relevo foi e ainda está sendo apropriado e ocupado, no qual acabam interferindo no equilíbrio dinâmico de infiltração e escoamento superficial. Isso tem gerados transtornos, principalmente no ambiente urbano, ligado aos períodos de chuvas intensas e constantes.

Foi possível verificar que os fundos de vale na área urbana apresentam uma concentração dos impactos ambientais relatados anteriormente. $\mathrm{O}$ que os tornam locais susceptíveis a erosão, assoreamento e alagamentos.

Neste sentido é importante também considerar além da forma como o relevo é apropriado e ocupado, a maneira como o espaço urbano é produzido, pois os agentes de produção do espaço (sejam eles do setor público ou privado), devem levar em consideração a dinâmica dos elementos naturais, ou seja, a dinâmica da natureza, envolve os solos (pedogênese- relação infiltração e escoamento da água), o relevo (morfogênese - erosão nas vertentes), os cursos d'água (processo de escoamento fluvial), bem como outros processos importantes. Os resultados obtidos demonstraram a importância de se considerar a dinâmica da natureza (aspectos físicos) e da sociedade (ações humanas) nas pesquisas sobre bacias hidrográficas, pois conhecer a morfodinâmica, os efeitos e as respostas do ambiente diante a ocupação de uma bacia hidrográfica urbana e realizar uma análise integrada dessas dinâmicas, isso pode fornecer uma série de dados e informações capazes de subsidiar o planejamento urbano e ambiental. Somente assim, será possível mitigar e até mesmo evitar impactos socioambientais, bem como a geração de áreas de risco ou de vulnerabilidade dos ambientes rurais e urbanos em uma bacia hidrográfica.

\section{AGRADECIMENTOS}

Os autores agradecem ao Instituto de Ciências Humanas do Pontal (ICHPO), o Programa de PósGraduação em Geografia do campus Pontal, ao Grupo de Pesquisa GEPDA, pelo apoio durante as atividades de campo e o Curso de Graduação em Geografia pela disponibilização do laboratório PEDOGEO para análise dos dados obtidos em campo e gabinete. Também ao grupo de pesquisa "Rede de Pesquisadores em Questões Ambientais Urbanas, vinculadas do Grupo de Pesquisa GAIA do Curso de Geografia da FCT UNESP. 


\section{REFERÊNCIAS}

BELTRAME, A. V. Diagnóstico do meio físico de bacias hidrográficas: modelo de aplicação. Editora da Associação Brasileira das Editoras Universitárias, Florianópolis: UFSC, 1994. 112 p;

BOTELHO, R. G. M. Bacias Hidrográficas Urbanas. In: GUERRA, J.T. Geomorfologia Urbana. Rio de Janeiro: Betrand Brasil, 2011;

CASSETI, Valter. Ambiente e Apropriação do Relevo. São Paulo: Editora Contexto, 1991. 84p;

CHRISTOFOLETTI, A. Geomorfologia. Editora, cidade, 1980, 188 p.;

GUERRA, A. J. T.; CUNHA, Sandra B. Geomorfologia: uma atualização de bases e conceitos. 2. ed. Rio de Janeiro: Bertrand Brasil, 1995. p. 472;

LANA, C. E.; ALVES, J. M. de P.; CASTRO, P. T. A. Análise morfométricas da bacia do rio do Tanque, MG-Brasil. REM: Revista Escola de Minas. Ouro Preto-Mg, 2001, vol 54 (2), p. 121-126; http://www.scielo.br/scielo.php?pid=S0370-44672001000200008\&script=sci abstract\&tlng=pt.

https://doi.org/10.1590/S0370-44672001000200008

MARCHETTI, D. A. B. Características da Rede de Drenagem e Formas de Relevo em três Unidades de solo de Piracicaba, SP. Pesq. Agropec. Bras., Brasília, 15(3), p. 349-358, jul 1980; Disponível em <https://seer.sct.embrapa.br/index.php/pab/article/viewFile/16580/10864>. Acessado em: 06/2019;

PEDRO MIYAZAKI, L. C. Dinâmicas de apropriação e ocupação em diferentes formas de relevo: análise dos impactos e da vulnerabilidade nas cidades de presidente prudente/SP e Marília/SP, Tese de Doutorado, Universidade estadual paulista faculdade de ciências e tecnologia campus de presidente prudente, 2014;

ROSS, J. L. S. Geomorfologia: ambiente e planejamento. São Paulo: Contexto, 2005. 85 p.;

STRAHLER, A. N. Quantitative Analysis of Watershed Geomorphology. Transactions, American Geophysical Union, Washington, v. 38, n. 6, p. 913-920, 1957. https://doi.org/10.1029/TR038i006p00913

SUGUIO, K. Geologia sedimentar. São Paulo: Blucher, 2003. 400 p.;

TRICART, J. Ecodinâmica. Rio de Janeiro: IBGE, SUPREN, 1977. 91 p;

TORRES, F. T. P.; MACHADO, P. J. de O. Introdução à hidrogeografia. São Paulo: Cengage Learning, 2012. 178p;

VENCESLAU, F. R.; PEDRO MIYAZAKI, L. C. Processos, análises e gestão de bacias hidrográficas em ambientes urbanos: o caso do córrego São José - Ituiutaba/MG. In: Revista Geografia em Atos Geoatos

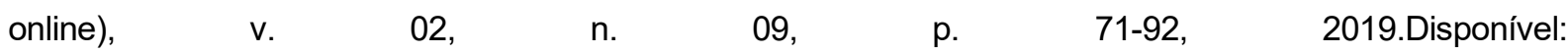
http://revista.fct.unesp.br/index.php/geografiaematos/article/view/6342/pdf 1 Acessado em dez. 2019;

Recebido em: $13 / 01 / 2020$

Aceito para publicação em: 02/07/2020 